\title{
Comment on a Proposal of Farmer et al. to Conserve the Specific Epithet tarda over the Specific Epithet anguillimortiferum in the Name of the Organism Known as Edwardsiella tarda
}

\author{
R. SAKAZAKI AND K. TAMURA
}

Department of Bacteriology 1, National Institute of Health, Kamiosaki, Shinagawa-ku, Tokyo 141, Japan

We express opposition to a proposal of Farmer et al. to conserve the specific epithet tarda over the specific epithet anguillimortiferum in the scientific name Eswardsiella tarda Ewing and McWhorter 1965. Farmer et al. justified their proposal by citing Principle 1 of the International Code of Nomenclature of Bacteria and Viruses 1958 (11) in the interest of stability in nomenclature and to avoid confusion in the literature. If one clings to the avoidance of a passing confusion, however, changes in classification and protection of priority of names cannot be realized. Paracolobactrum anguillimortiferum Hoshina 1962, which is the senior synonym of Edwardsiella tarda Ewing and McWhorter 1965 , was validly published based on the Bac. teriological Code 1958, although it was not published in the International Bulletin of Bacterial Nomenclature and Taxonomy and no type strain was designated. Therefore, the priority of the specific epithet anguillimortiferum over the epithet tarda in the name Edwardsiella tarda should be protected by Principle 6 and Rule 23 of the Bacteriological Code, 1976 Revision.

In 1975 Sakazaki and Tamura (17) pointed out that Edwardsiella tarda Ewing and McWhorter 1965 (5) is a later synonym of Paracolobactrum anguillimortiferum Hoshina 1962 (13) and that the specific epithet anguillimortiferum would have priority over the epithet tarda. They proposed the name Edwardsiella anguillimortifera to replace the name Edwardsiella tarda. However, this was opposed by Farmer et al. (6), who proposed that the specific epithet tarda be conserved over the epithet anguillimortiferum.

Farmer et al. emphasized that the name $E d$ warsiella tarda was published in the International Bulletin of Bacteriological Nomenclature and Taxonomy, whereas the name Paracolobactrum anguillimortiferum was published in the Japanese Bulletin of Scientific Fisheries, which is, they stated, " $a$ journal unlikely to reach working bacteriologists." They also indicated that Paracolobactrum anguillimortiferum does not appear in the Index Bergeyana
(4). It should be mentioned, however, that at that time the Bacteriological Code (11) had not prescribed that new names and combinations be published in the International Bulletin of Bacteriological Nomenclature and Taxonomy. The Japanese Bulletin of Scientific Fisheries, in which a description of Paracolobactrum an. guillimortiferum was published in English, may not reach all medical bacteriologists, but this does not invalidate the publication of Hoshina. The Index Bergeyana omitted not only the name Paracolobactrum anguillimortiferum, but also many legitimate names of bacteria, as indicated by Hatt and Zvirbulis (7) and Zvirbulis and Hatt $(19,20)$.

Farmer et al. suggested that, since the name Edwardsiella tarda was validly published 10 years ago, it has gained world-wide acceptance by bacteriologists. They also suggested that acceptance of the specific epithet anguillimortiferum would violate the intent of Principle 1 of the International Code of Nomenclature of Bacteria and Viruses 1958 (11) to avoid confusion in the literature. In reply, we cite some examples in recent nomenclature. Specific epithets of Leptospira icterohaemorrhagiae Inada, Ido, Hoki, Kaneko, and Ito 1916 (9), Acinetobacter anitratus (Schaub and Hauber) Brisou and Prévot 1954 (3), and Vibrio comma (Schroeter) Blanchard 1906 (2) had gained world-wide acceptance over 30 or more years. However, Leptospira interrogans (Stimson) Wenyon 1926 (18), Acinetobacter calcoaceticus (Beijerinck) Baumann, Doudoroff, and Stanier 1968 (1), and Vibrio cholerae Pacini 1854 (16) have been justified for those organisms, respectively, by the priority and legitimacy of their specific epithets $(10,13,14)$, although those names have seldom been used for the such organisms.

Farmer et al. cited Opinion 18 (12), as an example for assurance of their proposal, in which the Judical Commission of the International Committee on Bacteriological Nomenclature conserved typhi over typhosa as the specific epithet for the typhoid bacillus to minimize confusion in the literature, despite the fact typhosa 
had priority over typhi. However, the fame and importance in medical bacteriology may be different for Salmonella typhi and for Edwardsiella. As far as we have determined, no more than 20 papers dealing with the organism $E d$ wardsiella tarda have been published within the last 10 years. If the specific epithet tarda is replaced by the epithet anguillimortiferum, confusion in the literature will be minimized.

The Bacteriological Code is aimed at fixity of names and at avoiding confusion, but it sometimes creates it. Names may change because of a change in classification and in application of a legitimate, retroactive name. In such instances, a passing confusion in the literature may be inevitable. If avoidance of such confusion is stressed, changes in classification and protection of priority in nomenclature cannot be realized.

In the points of view mentioned above, we suggest that the priority of the specific epithet anguillimortiferum over the epithet tarda in the name Edwardsiella tarda should be protected by Principle 6 and Rule 23 of the International Code of Nomenclature of Bacteria, 1976 Revision (15).

\section{REPRINT REQUESTS}

Address reprint requeste to: Dr. R. Sakazaki, Department of Bacteriology 1, National Institute of Health, Kamiosaki, Shinagawa-ku, Tokyo 141, Japan.

\section{LITERATURE CITED}

1. Baumann, P., M. Doudoroff, and R. Y. Stanier. 1968. A study of the Moraxella group. II. Oxidase-negative species (genus Acinetobacter). J. Bacteriol. 95: 1520-1541.

2. Blanchard, R. 1906. Spirilles, spirochétes et autres microorganismes à corpes spiralé. Sem. Med. 26:1-5.

3. Brisou, J., and A. R. Prévot. 1954. Etudes de systematique bactérienne. $X$. Revision des espèces reuniés dans le genre Achromobacter. Ann. Inst. Pasteur (Paris) 86:722-728.

4. Buchanan, R. F., J. G. Holt, and E. F. Leasel, Jr. (ed.). 1966. Index bergeyana. The Williams \& Wilkins Co., Baltimore.

5. Ewing, W. H., A. C. McWhorter, M. R. Escobar, and A. H. Lubin. 1965. Edwardsiella, a new genus of Enterobacteriaceae based on a new species, $E$. tarda. Int. Bull. Bacteriol. Nomencl. Taxon. 15:33-38.

6. Farmer, J. J., III, D. J. Brenner, and W. A. Clark. 1976. Proposal to conserve the specific epithet tarda over the specific epithet anguillimortiferum in the name of the organism presently known as Edwardsiella tarda. Int. J. Syst. Bacteriol. 26:293-294.

7. Hatt, H. D., and E. Zvirbulis. 1967. Status of names of bacterial tara not evaluated in Index Bergeyana (1966). 1. Names published circa 1950-1967 exclusive of the genus Sabmonella. Int. J. Syst. Bacteriol. 17:171-225.

8. Hoshina, T. 1962. On a new bacterium, Paracolobactrum anguillimortiferum n. sp. Bull. Jpn. Soc. Sci. Fish. 28:162-164

9. Inada, R., Y. Ito, R. Hoki, R. Kaneko, and H. Ito. 1916. The etiology, mode of infection, and specific therapy of Weil's disease (Spirochaetosis icterohaemorrhagica). J. Expt. Med. 23:377-402.

10. International Association of Microbiological Societies. Subcommittee on the Taxonomy of Vibrios. 1966. Minutes of the Meeting, 29 January 1965. Int. J. Syst. Bacteriol. 16:135-142.

11. International Committee on Bacteriological Nomenclature (ed.). 1958. International code of nomenclature of bacteria and viruses. Iowa State University Press, Ames.

12. International Committee on Nomenclature of Bacteria. Judical Commitaion. 1963. Opinion 18: conservation of typhi in the binary combination Salmonella typhi. Int. Bull. Bacteriol. Nomencl. Taron. 13:31-32.

13. International Committee on Systematic Bacteriology. Subcommittee on the Taronomy of Moraxella and Allied Bacteria. 1974. Minutes of the closed meeting, 1 September 1973. Int. J. Syst. Bacteriol. 24:394-395.

14. International Committee on Systematic Bacteriology. Subcommittee on the Taxonomy of Leptospira. 1974. Minutes of the meetings 30 August -4 September 1973. Int. J. Syst. Bacteriol. 24:381-382.

15. Lapage, S. P., P. H. A. Bneath, E. F. Leseel, V. B. D. Skerman, H. P. R. Seeliger, and W. A. Clark (ed.) 1975. International code of nomenclature of bacteria, 1976 revision. American Society for Microbiology, Washington, D.C.

16. Pacini, F. 1854. Osservazione microscopiche e Daduzioni patologiche sul Cholera Asiatico. Gaz. Med. Ital. Toscana Firenze 6:405-412.

17. Sakazaki, R., and K. Tamura. 1975. Priority of the specific epithet anguillimortiferum over the specific epithet tarda in the name of the organism presently known as Edwardsiella tarda. Int. J. Syst. Bacteriol. 26:219-220.

18. Wenyon, C. M. 1926. Spirochaetes, p. 1233-1288. In C. M. Wenyon (ed.), Protozoology, vol. 2. William Wood and Co., New York.

19. Zvirbulis, E., and H. D. Hatt. 1969. Status of names of bacteria taxa not evaluated in Index Bergeyana (1966). Addendum II. Acetobacter to Butyrivibrio. Int. J. Syst. Bacteriol. 19:57-115.

20. Zvirbulie, E., and H. D. Hatt. 1969. Status of names of bacterial taxa not evaluated in Index Bergeyana (1966). Addendum III. Achromobacter to Lactobacterium. Int. J. Syst. Bacteriol. 19:309-370. 